\title{
EFEK PEMBEKUAN-PELELEHAN BERULANG TERHADAP MUTU SENSORI IKAN CAKALANG (Katsuwonus pelamis L)
}

\author{
Sandra Jenspiten Tatontos ${ }^{1}$, Silvana Danaintang Harikedua ${ }^{2}$, Eunike L. Mongi ${ }^{2}$, Djuhria \\ Wonggo $^{2}$, Lita A.D.Y. Montolalu ${ }^{2}$, Daisy M. Makapedua ${ }^{2}$, Verly Dotulong ${ }^{2}$ \\ ${ }^{1}$ Mahasiswa pada Program Studi Teknologi Hasil Perikanan FPIK UNSRAT Manado. \\ ${ }^{2}$ Staf Pengajar pada Program Studi Teknologi Hasil Perikanan FPIK UNSRAT Manado. \\ E-mail: fmentang@unsrat.ac.id
}

\begin{abstract}
Fish is one of the perishable food, freezing technique is an effective method in storage fishery products. The process of freezing and thawing can also cause damage to fish meat such as the occurrence of protein denaturation which results in the loss of water holding capacity and influence the decrease in sensory quality (odor, texture, color). This study aims to determine the effect of the freez-thaw cycle on Skipjack sensory quality. Freezing for 24 hours at $-24.2^{\circ} \mathrm{C}$ freezer temperature and thawing for 24 hours at refrigerator temperature $\pm 2,4^{\circ} \mathrm{C}$. Freez-thaw is done repeatedly, 1 time, 2 times, 3 times and 4 times. The results of the study showed that the more freezing-thawing processes carried out, the more affected the sensory quality. The results of this study indicate that after 4 times the freez-thaw cycle treatment affects the sensory quality of skipjack
\end{abstract}

Keyword: Freez-thaw cycle, sensory quality.

Ikan adalah produk pangan yang mudah mengalami kemunduran mutu (perishable food), teknik pembekuan adalah metode pengolahan dan penyimpanan yang efektif untuk produk hasil perikanan. Proses pembekuan juga dapat menyebabkan kerusakan pada daging ikan seperti terjadinya denaturasi protein, penurunan mutu sensori (aroma, tekstur, warna). Penelitian ini bertujuan untuk mengetahui efek dari pembekuan dan pelelehan secara berulang terhadap kualitas sensori ikan cakalang. Pembekuan dilakukan selama 24 jam pada suhu freezer $-24,2^{\circ} \mathrm{C}$ dan pelelehan dilakukan selama 24 jam pada suhu lemari es $\pm 2,4^{\circ} \mathrm{C}$. alur pembekuan-pelelehan dilakukan secara berulang, 1 kali, 2 kali, 3 kali dan 4 kali. Hasil penelitian memperlihatkan bahwa semakin banyak proses pembekuan-pelelehan yang dilakukan maka nilai mutu sensori. Penelitian ini menunjukkan bahwa setelah 4 kali perlakuan pembekuanpelelehan terhadap ikan cakalang terjadi penurunan pada penampakkan sensori.

Kata kunci: Pembekuan-pelelehan berulang, mutu sensori.

\section{PENDAHULUAN}

Ikan adalah produk pangan yang mudah mengalami kemunduran mutu (perishable food). Penurunan mutu ikan segar dapat disebabkan oleh kerja enzim maupun pertumbuhan mikroba. Penanganan ikan segar yang kurang hati-hati dan penerapan sanitasi yang kurang baik dapat mempercepat kemunduran mutu ikan. Untuk tetap menjaga kesegaran ikan sampai kepada konsumen maka wajib dilakukan penerapan rantai dingin (cold chain). Penanganan ikan segar dapat dilakukan dengan menerapkan suhu dingin baik melalui teknik pendinginan dan pembekuan untuk mencegah kemunduran mutu ikan.

Teknik pembekuan adalah metode penanganan dan penyimpanan yang efektif untuk produk hasil perikanan, dimana dapat menghambat pertumbuhan mikrobiologi dengan menghentikan reaksi enzimatik (Guo dan Liu, 2014).

Selanjutnya menurut Hallieret et.al., (2007) perlakuan pembekuan dan pelelehan yang dilakukan berulang dapat mengakibatkan perubahan pada bahan pangan seperti menurunnya mutu sensori, kandungan protein dan kehilangan kemampuan menahan kapasitas air (water holding capacity) sehingga mengakibatkan driploss.

Lee dan Park (2017) menyatakan bahwa driploss akan terjadi jika pembekuan dan pelelehan dilakukan berulang kali dan dapat mempengaruhi mutu sensori suatu bahan pangan.

Pembekuan adalah proses penurunan suhu bahan pangan sampai pada titik beku dan merubah sejumlah air menjadi es. Sedangkan menurut Adawyah (2008) pembekuan adalah proses pengambilan/pemindahan panas dari 
suatu bahan pangan. Berdasarkan metode pembekuan dapat dibagi menjadi dua metode yaitu pembekuan cepat dan pembekuan lambat. Dalam proses pembekuan yang harus diperhatikan adalah waktu pembekuan, karena dapat mempengaruhi pembentukan kristal es yang dalam ukuran besar yang ketika dilelehkan dapat membuat menurunnya kualitas bahan pangan. Pemikiran ini didasari dengan yang dinyatakan oleh Murniyati dan Sunarman (2000), tekstur daging ketika ikan lelehkan menjadi kurang baik dan menjadi beronggarongga.

Pembekuan lambat menghasilkan kristal dengan ukuran yang besar, kristal es ini mendesak dan merusak susunan jaringan daging (Rohanah 2002), hal yang sama yang dinyatakan oleh Murniyati dan Sunarman (2000) yaitu pembekuan lambat adalah pembekuan dengan thermal arrest time lebih dari 2 jam dalam membekukan sampel.

Rohanah (2002) Pembekuan cepat jika waktu pembekuan adalah kurang dari 20 menit untuk membekukan $1 \mathrm{~cm}$ bahan pangan Pembekuan cepat menghasilkan kristal yang kecil-kecil di dalam jaringan daging ikan. Jika dicairkan kembali, Kristal-kristal yang mencair diserap kembali oleh daging dan hanya sejumlah kecil yang lolos sebagai drip. Selanjutnya menurut Murniyati dan Sunarman (2000) yaitu pembekuan cepat adalah pembekuan dengan thermal arrest time tidak lebih dari 2 jam.

Ikan cakalang segar memiliki komposisi kimia protein 20,15\%, lemak 3,39\%, karbohidrat 2,35\%, kadar Air 73,03\%, kadar Abu 1,94\%.(Intarasirisawati et.al. 2011). Ikan cakalang memiliki tubuh yang membulat, memanjang dan garis lateral. Ciri khas dari ikan cakalang memiliki 4-6 garis berwarna hitam yang memanjang di samping bagian tubuh.

Ikan cakalang mempunyai ciri-ciri khusus yaitu tubuhnya mempunyai bentuk menyerupai torpedo (fusiform), bulat dan memanjang, serta mempunyai tapis insang (gill rakers) sekitar 53-63 buah.

\section{METODOLOGI PENELITIAN}

\section{Bahan}

Bahan yang digunakan dalam penelitian ini adalah ikan cakalang segar, larutan buffer fosfat, larutan Kalium Iodida (KI), larutan potassium fosfat, larutan buffer, reagen Lowry (A, B, C, D dan E), larutan BSA.
Alat

Alat-alat yang digunakan dalam penelitian ini adalah peralatan gelas kimia, rak tabung, tabung reaksi, pipet, tips, shaker incubator, vorteks refrigerator, sentrifugasi, spektrofotometer uv-vis, kuvet, talenan, blender, botol kaca, label, alumunium foil, pisau, termometer, kulkas (freezer), coolbox.

\section{Prosedur Analisa Sensori Tingkat Kesegaran Ikan SNI}

Analisa sensori menggunakan score sheet yang sudah dipersiapkan sebelumnya. Panelis diminta untuk menilai berdasarkan kriteria dan spesifik mutu yang disiapkan dalam bentuk score sheet organoleptik, dengan skor terendah adalah angka 1 dan skor tertinggi angka 9. Pengujian organoleptik ikan segar mengacu pada SNI2729:2013, tentang ikan Segar. Pengujian organoleptik meliputi mata, daging, insang, aroma, kenampakan setelah pelelehan, bau, daging dan tekstur yang mana sampel telah mengalami pembekuan pelelehan berulang selama 0 kali, 1 kali, 2 kali, 3 kali, 4 kali. Dan dinilai dengan menggunakan score sheet organoleptik ikan segar.

Prosedur pengujian tingkat kesegaran ikan:

1. Persiapan 10 panelis terlatih;

2. Pengujian dilakukan secara individual;

3. Persiapan pengukuran suhu dan berat sampel;

4. Sampel disajikan untuk dinilai oleh panelis;

5. Panelis dipersilahkan masuk ke ruang jika semua contoh sampel yang diuji siap;

6. Panelis diminta menilai mutu sensori semua sampel yang disajikan (mata, insang, daging, dan aroma) dengan score sheet dan panduan yang sudah disiapkan pula;

7. Selesai penilaian dilanjutkan dengan tabulasi data terhadap semua hasil penilaian.

\section{HASIL DAN PEMBAHASAN}

\section{Analisa Sensori \\ Mata}

Nilai rata-rata organoleptik (mata) ikan cakalang (Katsuwonus pelamis L) dari semua perlakuan pembekuan-pelelehan berulang dapat dilihat pada Gambar 1. Gambar 1 menunjukkan bahwa proses perlakuan pembekuan-pelelehan berulang mengalami penurunan nilai sensori dari aspek mata. Nilai organoleptik tertinggi berada pada sampel 0 yaitu sampel yang tidak 
mengalami perlakuan pembekuan-pelelehan berulang yaitu dengan nilai rerata 7,1 sedangkan nilai rerata organoleptik terendah pada sampel 4 dengan perlakuan 4 kali pembekuan-pelelehan berulang dengan nilai rerata yaitu 3,2, menurut SNI 2729:2013 tentang ikan segar, sampel dengan nilai organoleptik 7 memiliki ciri-ciri mata cembung, kornea agak berkabut, pupil agak redup sedangkan sampel dengan nilai 3 memiliki ciriciri mata cekung, pupil keputihan, tenggelam.

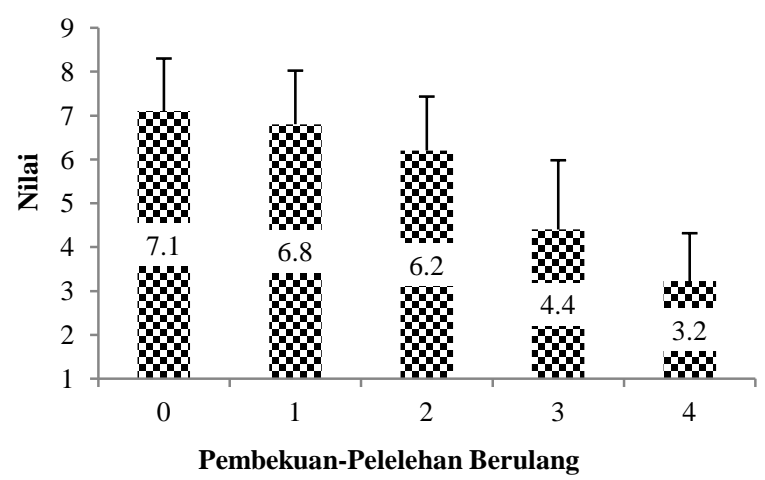

Gambar 1. Histogram Hasil Penilaian Organoleptik Mata.

\section{Daging}

Nilai rata-rata organoleptik (daging) ikan cakalang dari semua perlakuan pembekuan-pelelehan berulang dapat dilihat pada Gambar 2. Gambar 2 menunjukkan bahwa proses perlakuan pembekuan-pelelehan berulang pada sampel yang diteliti mengalami penurunan nilai organoleptik dari segi daging. Dari gambar tersebut nilai organoleptik tertinggi berada pada sampel 0 yang tidak mengalami perlakuan pembekuan-pelelehan berulang yaitu dengan nilai rerata 8,1 sedangkan nilai rerata organoleptik terendah pada sampel E dengan perlakuan 4 kali pembekuan-pelelehan berulang dengan nilai rerata yaitu 4,7 dari data di atas menurut SNI 2729:2013 tentang ikan segar, sampel dengan nilai organoleptik 8 memiliki ciri-ciri kemerahan, tidak transparan, daging kompak, darah tulang belakang merah sedangkan sampel dengan nilai 4 memiliki ciri-ciri daging pucat, lunak, berlendir, bau tengik, darah berwarna cokelat.

\section{Insang}

Nilai rata-rata organoleptik (insang) ikan cakalang dari semua perlakuan pembekuan-pelelehan berulang dapat dilihat pada Gambar 3. Gambar ini menunjukkan bahwa proses perlakuan pembekuan-pelelehan berulang pada sampel yang diteliti mengalami penurunan nilai organoleptik dari segi insang. Dari gambar tersebut nilai organoleptik tertinggi berada pada sampel 1 yang tidak mengalami perlakuan pembekuan-pelelehan berulang yaitu dengan nilai rerata 7,6 sedangkan nilai rerata organoleptik terendah pada sampel 4 dengan perlakuan 4 kali pembekuan-pelelehan berulang dengan nilai rerata yaitu 4,4. dari data di atas menurut SNI 2729:2013 tentang ikan segar, sampel dengan nilai organoleptik 7 memiliki ciri-ciri insang merah kecokelatan, ujung filament pucat, berlendir sedangkan sampel dengan nilai 4 memiliki ciri-ciri insang cokelat pucat kehijauan, ujung filament putih, bau menusuk, berlendir.

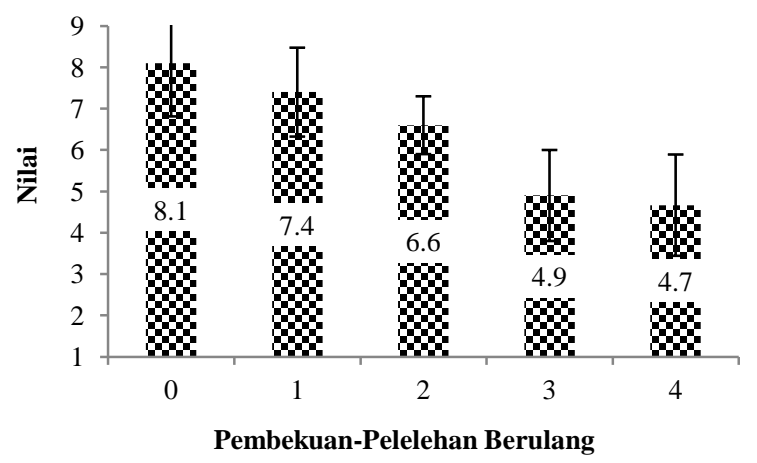

Gambar 2. Histogram Hasil Organoleptik Daging.

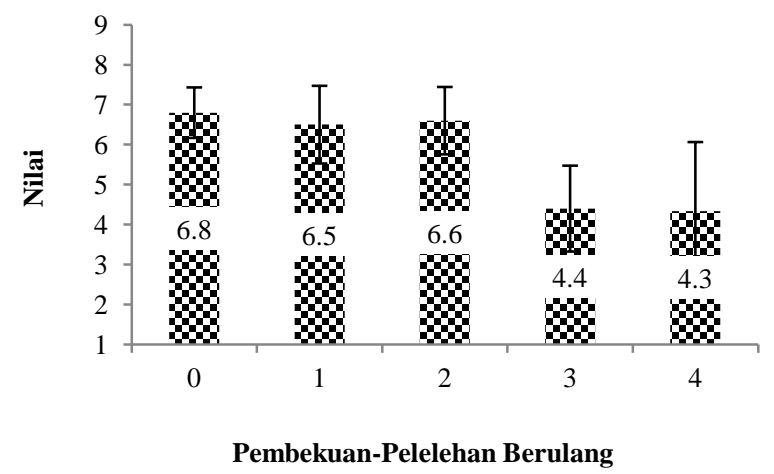

Gambar 3. Histogram Hasil Organoleptik Insang.

\section{Aroma}

Nilai rata-rata organoleptik (aroma) ikan cakalang dari semua perlakuan pembekuan-pelelehan berulang dapat dilihat pada Gambar 4. Gambar 4 menunjukkan bahwa proses perlakuan pembekuan-pelelehan berulang pada sampel yang diteliti mengalami penurunan nilai organoleptik dari segi aroma. Dari gambar tersebut nilai organoleptik tertinggi berada pada sampel 0 yang tidak mengalami perlakuan pembekuan-pelelehan berulang yaitu dengan nilai rerata 7,6 
sedangkan nilai rerata organoleptik terendah pada sampel 4 dengan perlakuan 4 kali pembekuan-pelelehan berulang dengan nilai rerata yaitu 4,2. dari data di atas menurut SNI 2729:2013 tentang ikan segar, sampel dengan nilai organoleptik 7 memiliki ciri-ciri aroma bau amis lembut sedangkan sampel dengan nilai 4 memiliki ciri-ciri aroma bau menusuk, bau Tengik.

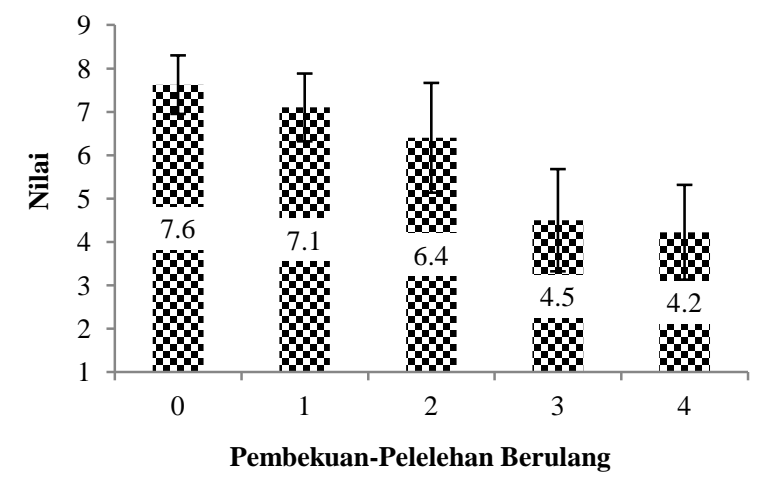

Gambar 4. Histogram Hasil Organoleptik Aroma.

Secara keseluruhan data uji sensori menunjukkan bahwa proses pembekuanpelelehan berulang dapat menurunkan kualitas sensori ikan. Hal ini bisa disebabkan karena dalam pembekuan proses enzimatis terhambat tapi pada proses pelelehan dalam suhu dengan proses enzimatis kembali aktif dan masih belum bisa menghambat kerja enzim seperti yang dinyatakan oleh Nurjanah (2011) bahwa enzimatis masih bekerja dalam suhu pendinginan (chilling) dan menguraikan senyawa makro menjadi mikro. Faktor yang lain yang mempengaruhi adalah dikarenakan proses pembekuan-pelelehan berulang menghasilkan driploss dalam jumlah besar, driploss ini akan mempengaruhi tekstur ikan dan penampakkan ikan secara keseluruhan.

Semakin banyak cairan air keluar dari daging maka dapat diartikan bahwa kekuatan daging menahan air menurun (water holding capacity) dan faktor yang berhubungan dengan daya ikat air oleh protein daging. Dengan perlakuan pembekuan-pelelehan berulang terhadap sampel berpengaruh pada kekuatan daging untuk menahan air. Lawrie, (2003) juga menyatakan bahwa meningkatnya temperatur akan mempengaruhi peningkatan denaturasi protein yang merupakan salah satu penyebab daya ikat air menurun yang berdampak pada daging akan mengalami kehilangan cairan (driploss) dan menyebabkan tingkat kesegaran ikan semakin menurun yang mana mempengaruhi mutu sensori dari sampel selama pembekuan-pelelehan berulang berlangsung.

\section{KESIMPULAN DAN SARAN}

\section{Kesimpulan}

Semakin banyak proses pembekuanpelelehan berulang akan semakin mempengaruhi mutu sensori ikan cakalang (Katsuwonus pelamis L). dengan seiring banyaknya proses pembekuan-pelelahan akan semakin mempengaruhi mutu ikan cakalang. 4 kali proses pembekuan-pelelahan berpengaruh terhadap sampel kehilangan kemampuan menahan air dan menurunkan mutu sensori sampel pada semua aspek penilaian.

\section{Saran}

Untuk pengujian berikutnya perlu diperhatikan berat sampel dan keseragaman sampel, tiap sampel harus dalam keadaan masih segar dan dalam berat yang sama agar mendapatkan hasil yang baik. Dan untuk penelitian berikutnya untuk lebih mengetahui lebih jauh tentang efek mutu sensori ikan cakalang selama proses pembekuan-pelelehan berulang, perlu dilakukan pengujian dengan variasi banyaknya proses pembekuan-pelelehan.

\section{DAFTAR PUSTAKA}

Adawyah, Rabiatul. 2008. Pengolahan dan Pengawetan Ikan. Edisi Pertama. Jakarta. PT. Bumi Aksara.

Guo, Y., B., Xia., X.,Yu., T., \& Liu, Q. 2014. Changes in phsyco-chemical and protein structural properties of common carp (Cyprinus carpio) muscle subjected to different freeze-thaw cycle. Jurnal of aquatic food product techonology. 23(6), 579-590.

Hallier, A., Chevallier, S., Serot, T. And Prost, C., 2007. Freezing-thawing effects on the color and texture of European catfish flesh. International Journal of Food Science and Technology, 43: 1253-1262

Intarasiriswat C, Benjakul S, dan Visessanguan W. 2011. Chemical compositions of the roes from skipjack, tongol, and bonito. Journal Food Chemistry 124 (11): $1328-1334$.

Lawrie, RA. 2003. Ilmu Daging. Universitas Indonesia. Jakarta.

Lee. J., and Park. J. W. 2017. Roles Of TMAOase In Muscle And Drips Of Alaska Pollock Fillets At Various Freeze/Thaw Cycle. Journal of Food Processing And Preservation. Hal 1.

Murniyati, A. S dan Sunarman. 2000. Pendinginan Pembekuan dan Pengawetan Ikan. Percetakan Kanisius. Yogyakarta

Rohanah, A. 2002. Pembekuan. Fakultas Pertanian Jurusan Teknologi Program Studi Mekanisasi Universitas Sumatera Utara. Medan. 